\title{
Assessing the Impact of Short Training on First-Aid among Government Employees and Community People in the Rural Parts of Karnataka
}

\author{
Dr. Shivabasayya*1 ${ }^{1}$, Dr. Gulappa Devagappanavar ${ }^{2}$ \\ ${ }^{I}$ Master of Public Health PG Scholar, School of Environmental Science, Public Health, and Sanitation \\ Management. Karnataka State Rural Development and Panchayat Raj University, Gadag, Karnataka. \\ ${ }^{2}$ Guest Faculty, Department of Public Health, School of Environmental Science, Public Health, and \\ Sanitation Management. Karnataka State Rural Development and Panchayat Raj University, Gadag,
} Karnataka.

*Corresponding Author: Dr. Shivabasayya, Master of Public Health PG Scholar, School of Environmental Science, Public Health, and Sanitation Management. Karnataka State Rural Development and Panchayat Raj University, Gadag, Karnataka.India.

\begin{abstract}
Background: First-aid providing was the initial care for an illness or injury, by a non-expert but the trained person, till medical treatment can be accessed in the period of Golden Hour. Appropriate knowledge on the prevention, control, and management of common - illnesses and injuries will play a long way in reducing morbidity and mortality. Hence training is a good step in reducing such mortalities. In this, we have assessed the impact of training on First-Aid among the government employees and community people.
\end{abstract}

Methodology: An intervention study was conducted in KSRDPRU adopted 5 villages Gadag Karnataka, south India. Data were obtained from the 246 participants using a questionnaire and assessed their Knowledge, attitude, and practices (KAP) about the first aid for common medical emergencies.

Results: In a present study among the government employees and community people, the majority have the average knowledge in the pre-test, where has after the short training their knowledge increased most over at the time( $85 \%$ \& Above) in the post-test. All the respondents showed a positive attitude towards learning and training of first aid. In the government employees, few have good practices in the pre-test, where has after the short training their first aid practices were increased to $85 \%$. In the community people, very few people know the proper first aid practices in the pre-test, where has after the short training there practices increased above $55 \%$.

Conclusion: There was inadequate Knowledge, practices of first aid. The formal training is needed for them to provide the correct and effective first aid services. The short training showed a positive impact on participants.

Keywords: First-aid; Knowledge; Attitude and Practice; Intervention; Short training; Life-saving skills; Karnataka

\section{INTRODUCTION}

First aid is the first assistance or treatment given to a casualty or a sick person for any injury or sudden illness before the arrival of an ambulance, the arrival of a qualified paramedical or medical person, or before arriving at a facility that can provide professional medical care(1)(2). Individuals and communities are the ability to respond effectively in a crisis. As such, the Movement must advocate for and provide effective first aid education that is accessible to everyone and engages the learner to ultimately respond to an emergency appropriately(3).It is estimated that $50 \%$ of death occurs within $1^{\text {st }}$ hour of the accident, $30 \%$ between 1 hour and a week. And $20 \%$ occur after 1 week. The "golden hour" and hour highlight the importance of early trauma care important factor responsible for increasing secondary injuries and complication are nonavailable of first aid(4)(5). India lacks adequate infrastructure facilities which can lead to loss of life. The increasing competition in class has led to a high-stress level and consequently. The knowledge of first aid when properly applied can mean the difference between temporary or permanent injury, rapid recovery, or long term 
disability and difference between life \& death(6). The First-aid provider should also have adequate knowledge and skills about what he is doing, and be encouraging and reassuring to the victims(7).

Hence this study aims to Assessment of knowledge, attitude, and practice regarding first aid measures and the impact of short training among selected government employees, community people in 5 villages of field practice area of KSRDPR University, in GadagTaluk, Gadag District, Karnataka state, India.

\section{Materials ANd Methods}

\section{Study Design and Setting}

A community-based cross-sectional study was conducted in the rural areas of GadagTaluk. Hulakoti, Binkadakatti, Kurthkoti, Nagavi, and Kalasapura these five villages were selected using a simple random technique and before the training data was obtained using a pre-tested semi-structured questionnaire. Following which, education and training regarding first aid were provided to them with the help of PowerPoint presentation, demonstration videos, and charts. After the short training, the same components were reassessed using the same questionnaire.

\section{Participants}

In each village number of the government of employees was enlisted and the same number of community people were included in the study to give equal opportunity and to avoid the technical error.

Government Employees: School teachers, Panchayat development officer, doctors, ANM, Anganwadi worker, Village accountant.

Community People: General population, students, youths, women self-help groups, and gram panchayat members.

Variables: Independent variables: Knowledge, attitude, and practice among the study participants.

Dependent variables: Age, gender, occupation, level of education, and marital status.
Data Sources: The primary data was obtained by administering the pre-tested semi-structured questionnaire.

Government employees' data was collected at their working places and community people data was obtained in the common congruence places of the villages.

Before Training: Socio-demographic details, participant's responses were recorded against their knowledge, attitude, and practice about the first aid services.

After Training: participant's response was recorded against their knowledge, attitude, and practice about the first aid services using the same questionnaire.

\section{Study Size}

The sample for the study comprised of 246 members. The sample was selected by purposive sampling technique. Written Informed Consent was obtained from all study participants before enrollment into the study, the data was collected and between 1 July 2019 and 31 August 2019. Data on the knowledge, attitude, and practice of first aid among the participants was collected using a self-administered semi-structured questionnaire. In cases were the participant could not read and/or understand some medical terms, the research assistants would interpret the questionnaire into local languages. We have provided short training to all study participants, after the short training based on the availability of the study participants post-test was conducted in each village using the same questionnaire. how many Government employees are given the consent to participate, the equal number of community people was chosen in each village to avoid the sampling error.

\section{Statistical Methods}

Data was entered into the excel sheet and analyzed using SPSS v20; results were expressed in frequency, percentages, and graphs.

\section{RESULTS}

Table1. Socio-Demographic details of the study participants (n-246)

\begin{tabular}{|l|l|}
\hline Characteristics & Frequency (\%) \\
\hline 1.GENDER & \\
\hline Male & $118(47.96)$ \\
\hline Female & $128(52.03)$ \\
\hline 2.AGE (years) & \\
\hline$<20$ & $54(21.95)$ \\
\hline $20-24$ & $3(01.21)$ \\
\hline
\end{tabular}


Assessing the Impact of Short Training on First-Aid among Government Employees and Community People in the Rural Parts of Karnataka

\begin{tabular}{|l|l|}
\hline $25-29$ & $26(10.56)$ \\
\hline $30-34$ & $32(13.00)$ \\
\hline $35-45$ & $81(32.92)$ \\
\hline$>46$ & $50(20.32)$ \\
\hline 3.MARITAL STASTUS & \\
\hline Single & $67(27.23)$ \\
\hline Married & $174(70.73)$ \\
\hline Widow/widowers & $05(02.03)$ \\
\hline 4.EDUCATION & \\
\hline Professional degree & $04(01.62)$ \\
\hline Graduate/postgraduate & $62(25.20)$ \\
\hline Intermediate/post-high school diploma & $55(22.35)$ \\
\hline High school certificate & $71(28.86)$ \\
\hline Middle school certificate & $29(11.78)$ \\
\hline Primary school certificate & $24(09.75)$ \\
\hline Illiterate & $01(00.40)$ \\
\hline 5.OCCUPATION & \\
\hline Professional (white-collar) & $07(02.84)$ \\
\hline Semi-professional & $36(14.63)$ \\
\hline Clerical, Shop-Owner / Farm & $28(11.38)$ \\
\hline Skilled worker & $40(16.26)$ \\
\hline Semi-skilled worker & $52(21.13)$ \\
\hline Unskilled worker & $31(12.60)$ \\
\hline Unemployed & $52(21.13)$ \\
\hline 6. INCOME & \\
\hline Upper & $09(03.65)$ \\
\hline Upper-middle & $44(17.88)$ \\
\hline Lower-middle & $65(26.42)$ \\
\hline Upper-lower & $69(28.04)$ \\
\hline Lower & $59(23.98)$ \\
\hline & \\
\hline
\end{tabular}

\section{Socio-Demographic Details}

The study consisted of 246 participants (123 government employees and 123 community people) in all 5 villages. Male participants were $47.96 \%$ and female participants are 52.03\%. Most of the participants were in the age group of 35-45 years in government employees and community people were in the age group of 1246 years. The majority of the participants were married. All most all government employees finished by intermediate and graduate and some are professional. And most of the community participants were high school certificates and few are illiterate. The majority of government employees are skilled and semi-skilled workers, and some are professionals. In the community, most of the participants are skilled and unskilled workers but few are unemployed. Overall participants are economical upper-lower, lowermiddle-class few are lower class.

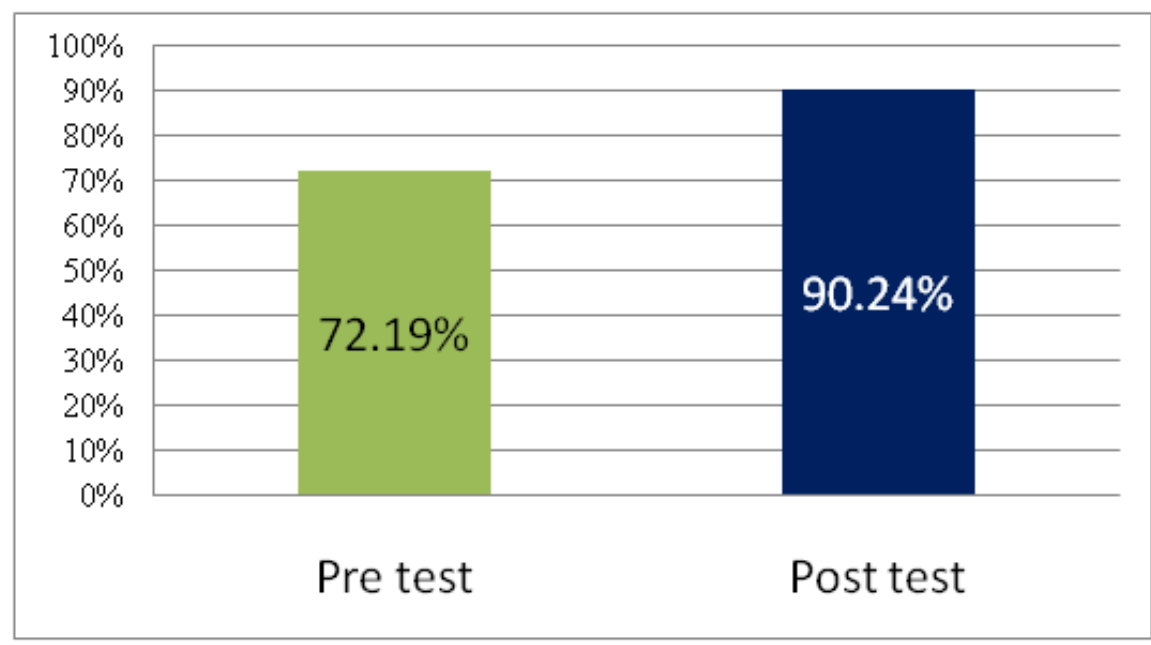

Figure1. Comparison of pre-test and post-test knowledge among government employees (n-123) in 5 villages 
Assessing the Impact of Short Training on First-Aid among Government Employees and Community People in the Rural Parts of Karnataka

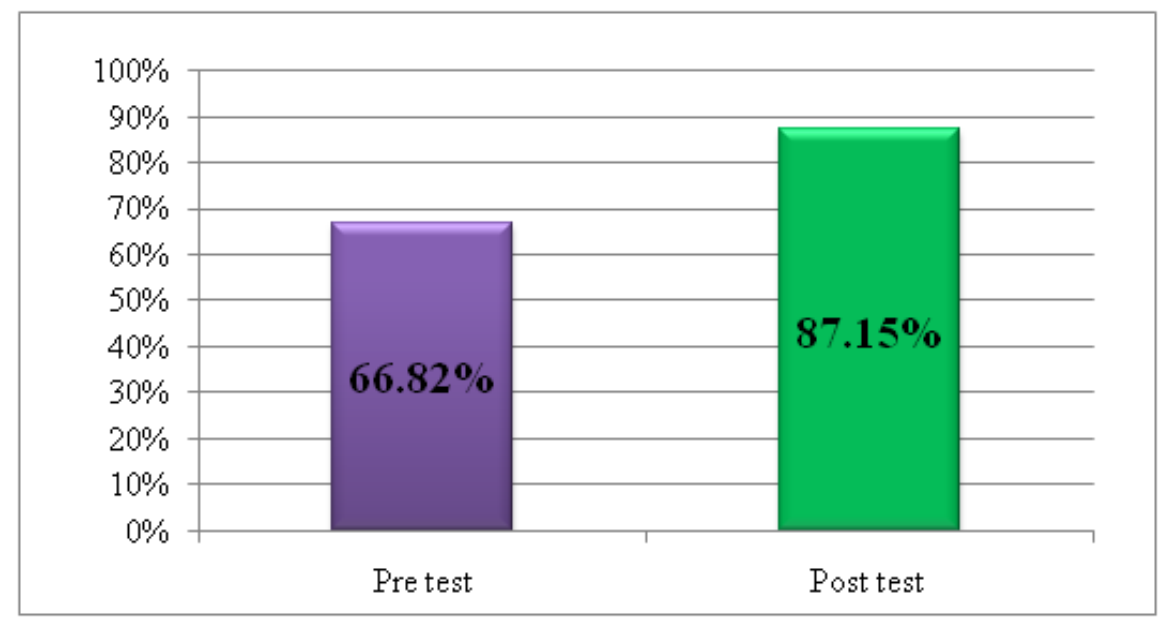

Figure2. Comparison of pre-test and post Knowledge among community participants (n-123) in 5 villages

\section{Knowledge about First-Aid}

In this study among the government employees majority of people havegood knowledge of the pre-test, where has after the short training, their knowledge was increased most over at the time of the post-test. Among the community majority of people has good knowledge in the pre-test, where has after the short training, their knowledge was increased most over at the time in the post-test, and when compared among both the groups short training was made an impact on their knowledge.

The short training doesn't make any impact $(\mathrm{P}>0.05)$ onthe Government employees in the category of daily routine activities related to first-aid. (Fig.1\&2)

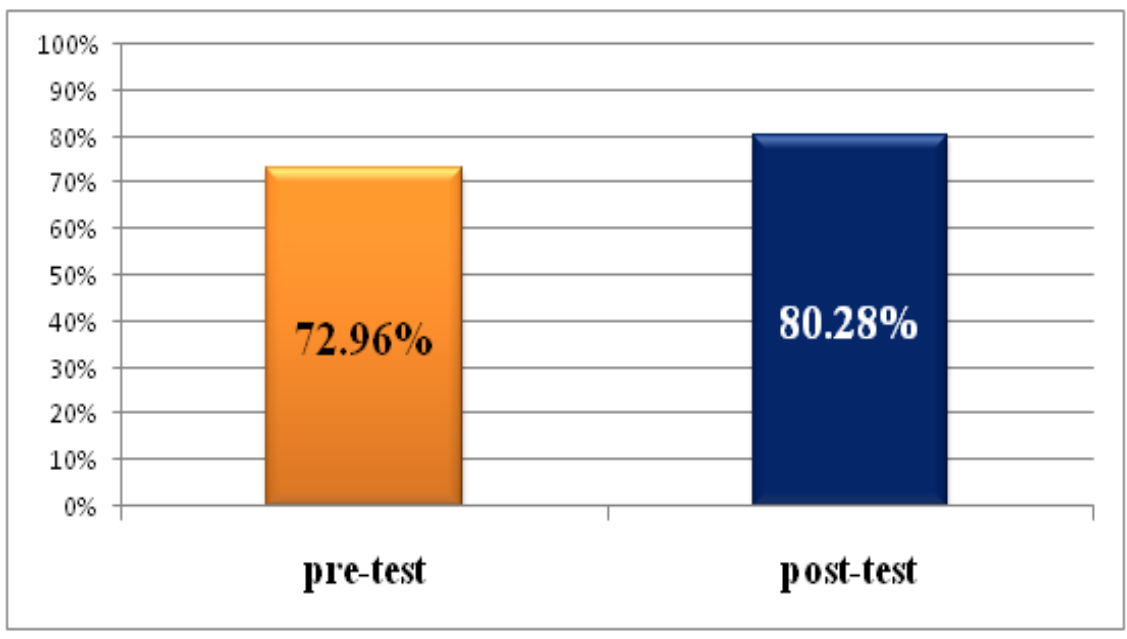

Figure3. Comparison of pre-test and post-test of Attitudes among government employees (n-123) in 5 villages

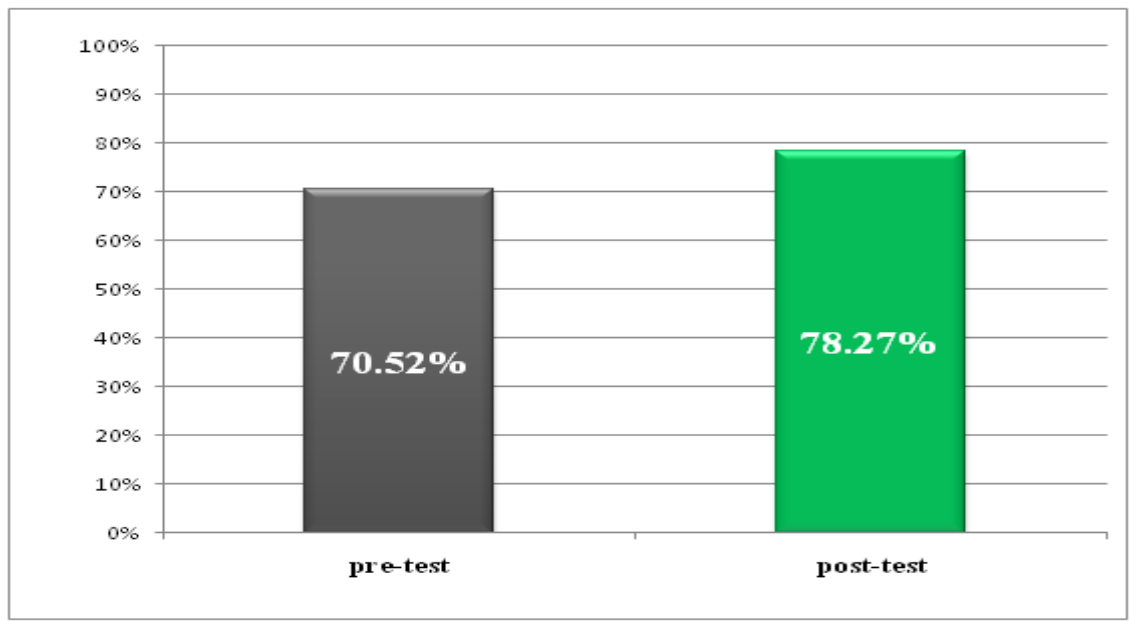

Figure4. Comparison of pre-test and post-test of Attitudes among community people (n-123) in 5 villages 
Assessing the Impact of Short Training on First-Aid among Government Employees and Community People in the Rural Parts of Karnataka

\section{Attitudes about First-aid}

In the current study among the government employees, the majority of the respondents showed a positive attitude towards giving and learning first aid. Where has after the short training their attitude was increased to most over at the time in the post-test.
The majority of people have an average attitude in the pre-test, where has after the short training their attitude was increased most over at the time in the post-test. Except in one variable, our short training was made an impact on both the groups and its significant $(\mathrm{P}<0.05)($ Fig.3\&4)

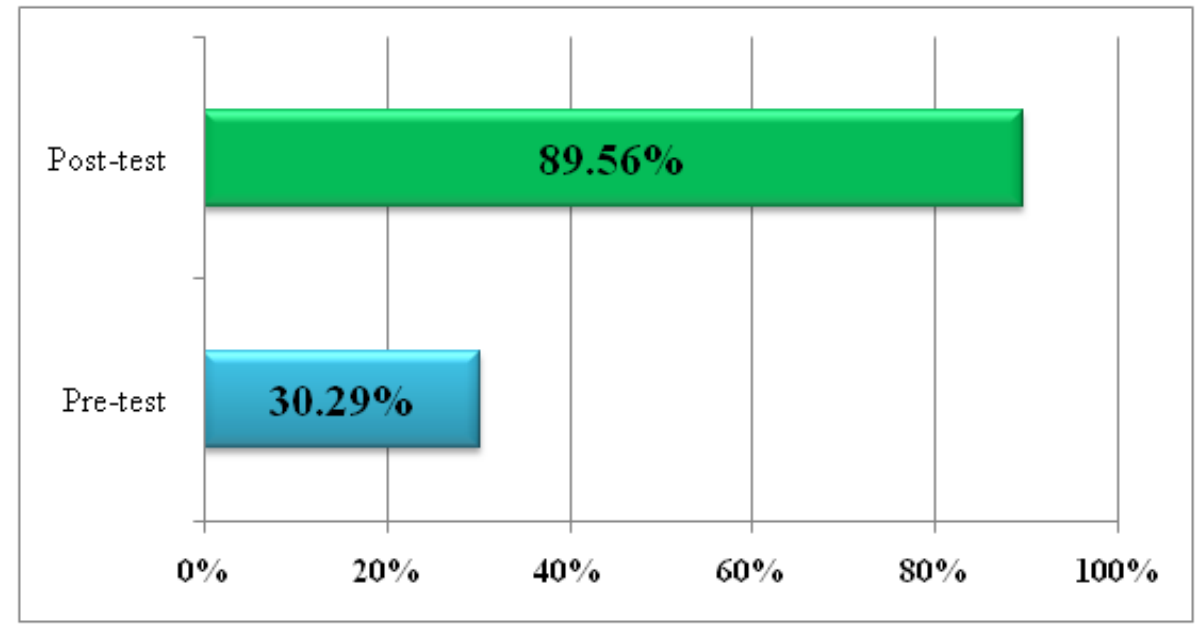

Figure5. Comparison of pre-test and post-test practices among Government employees (n-123) in 5 villages

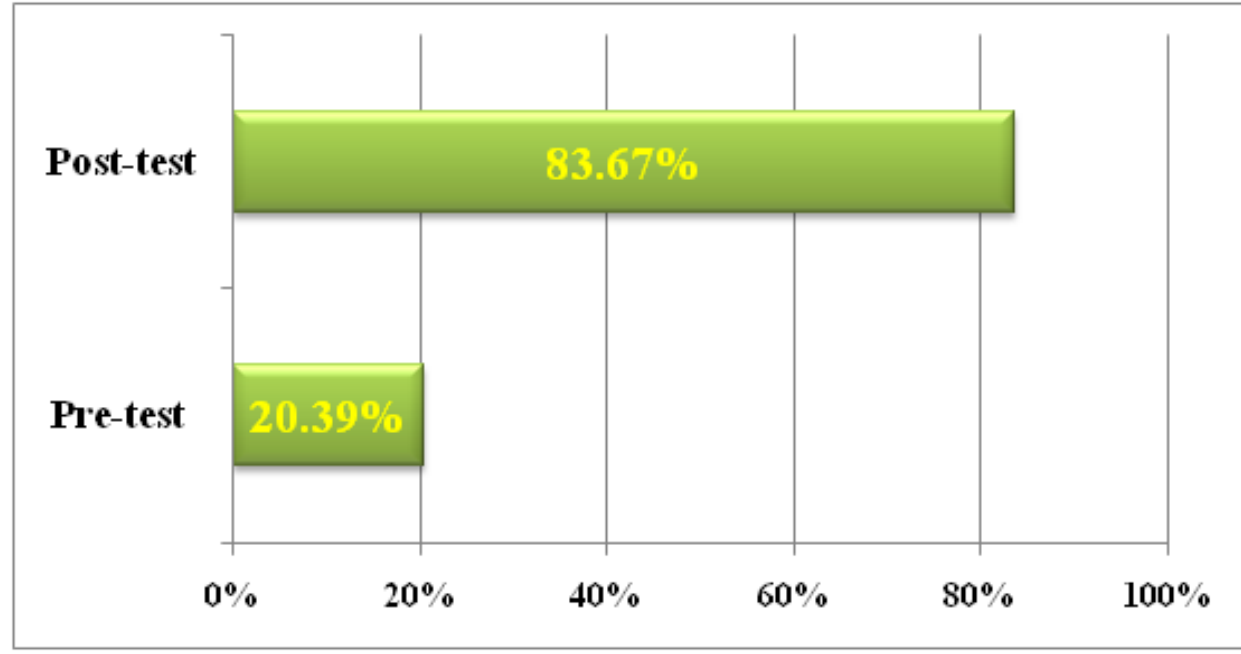

Figure6. Comparison of pre-test and post-test practices among Community people (n-123) in 5 villages

\section{Practices about First-aid}

In the present study among the government employees, few people have good practices in the pre-test, where has after the short training their first-aid practices was increased most over at the time in the post-test.

In the community people, very few people know the proper first aid practices in the pre-test, where has after the short training their practices were increased most over at the time in the posttest.On both, the groups our short training was made an impact and it's significant in all aspects of first-aid practices $(\mathrm{P}<0.05)($ Fig. $5 \& 6)$

\section{DISCUSSION}

\section{Knowledge about First-Aid}

In our study short training about the first-aid made impact on the government employees in all variables except in daily routine activities. A study conducted on school teachers in Ethiopia found similar findings(8). Another study conducted on drivers in Turkey showed similar findings(9).

In the current study, short training was made an impact on the community people. The study conducted on school children at Ahmadabad, Maharashtra, Pune, Tamilnadu, and Chandigarh found similar results(10)(11)(12)(13)(14). 
Assessing the Impact of Short Training on First-Aid among Government Employees and Community People in the Rural Parts of Karnataka

Another study conducted at Bahna city of Egypt and UAE found similar findings(15)(16).

\section{Attitudes about First-aid}

In this study, it was found that short training about the first-aid was made an impact on the government employees. Similar findings found in a study conducted at Turkey on school teachers(17) and UAE on medical employees showed the same impact(16).

Short training about first-aid showed a positive impact on community people. a similar study was conducted at Ahmadabad (10). Another study conducted on community people at UAE found a positive impact(16).

\section{Practices about First-aid}

In the present study, short training was a positive impact on government employees. A similar study conducted at Turkey on drives and teachers in Iran showed positive findings(9)(18). Another study conducted on bus drivers, conductors, and traffic police at Zambia showed similar findings(19).

In the current study, the first-aid practices increased after the short training in the community people. A similar study conducted at Mandya on nursing students (20), on self-groups at Mangalore(21), on mothers at Bangalore district(22) and Chandigarh on school students showed similar findings(11). Similar advice was found in the review article on Snakebite first$\operatorname{aid}(23)$.

\section{CONCLUSION}

The current study was conducted in rural areas, short training on first-aid made a positive impact on the study participants, and similar training is needed to train the urban area population to provide the effective first-aid and to reduce the morbidity and mortality.

\section{Ethical Clearance}

Ethical clearance was obtained from the ethics committee of Karnataka State Rural Development and Panchayath Raj University Gadag.

\section{ACKNOWLEDGMENT}

I would like to acknowledge Dr. Suresh Kishanrao, Honorary Professor of KSRDPR University, Gadag for their valuable support and guidance.

\section{REFERENCES}

[1] Indian Red Cross society. Indian first aid manual 2016. Vol. 7th edition. 2016. 1-346 p.
[2] World Health Organization (WHO).Guidelines for trauma quality improvement programmes. 2009.1-114 p.

[3] Www.ifrc.org. International Federation of Red Cross and Red Crescent Societies-2016. 2016. $1-190 \mathrm{p}$.

[4] International Federation of Red Cross and Red Crescent societies. Law and first aid: Promoting and protecting life-saving action. www.Ifrc. Org. 2016. 1-32 p.

[5] World Health Organization (WHO). Emergency Response Framework. 2013.1-59 p.

[6] Pallavisarji U, Gururaj G, Girish RN. Practice and Perception of First Aid Among Lay First Responders in a Southern District of India. Arch Trauma Research. 2013;1(4):155-60.

[7] World Health organization. Psychological first aid : Guide for field workers. 2011. 1-64 p.

[8] Ganfure G, Ameya G, Tamirat A, Lencha B, Bikila D. First aid knowledge, attitude, practice, and associated factors among kindergarten teachers of Lideta sub-city Addis Ababa, Ethiopia. PLoS One. 2018;13(3):1-15.

[9] Prof. Dr.Nurhan Bayraktar, Dr.Sevilay, Dr.Hayriye DHB. Evaluating the Effectiveness of a First Aid Training Course on Drivers. Hacettepe Univ Fac Heal Sci Nurs J [Internet]. 2009;47-58. Available from: http://hacettepehe msirelikdergisi.org/pdf/pdf_HHD_63.pdf

[10] Rachna K, Sheetal V, Parth M, Aashinee M, Abhijeet M, Shailee M, et al. Impact of training on knowledge and attitude regarding first aid among students of schools of Ahmedabad. Natl J Community Med [Internet]. 2017;8(7):380-4. Available from: http://proxy.lib.umich. edu/ login?url=http:// search. ebscohost.com/ login. aspx?direct=true $\& \mathrm{db}=1 \mathrm{hh} \& \mathrm{AN}=20183090390$ \&site $=$ ehost-live $\&$ scope $=$ site $\% 0$ Ahttp://www. njcmindia.org/home/abstrct/1050/July\%0Aemai 1: dr_shvyas@yahoo.com

[11] Goel S, Singh A. Comparative Impact of Two Training Packages on Awareness and Practices of First Aid for Injuries and Common Illnesses among High School Students in India. Int Electron J Health Educ [Internet]. 2008;11:6980. Available from: https://files.eric.ed. gov/ full text/EJ798655.pdf

[12] Devyani.S.Shinde DVSS, R.Shinde DS. Knowledge of high School students in Pune about first aid and the effect of training on them. Indian J Basic Appl Med Res. 2015;5(December):556-9.

[13] Chandrachood M V, Acharya S. A study to assess the effectiveness of training on first aid among students of industrial training institute in tribal area of Thane district, Maharashtra. Int J community Med Public Heal. 2019;6(4):1573-7. 
Assessing the Impact of Short Training on First-Aid among Government Employees and Community People in the Rural Parts of Karnataka

[14] Muneeswari B. A study to assess the effectiveness of planned health teaching programme using child-to -child approach on knowledge of selected first aid measures among school children in selected schools at Dharapuram in Tamil Nadu, India. Glob J Med Public Heal. 2014;3(1):1-19.

[15] Mohammed AA. The Influence of Training Program on Knowledge and Practices of Preparatory Schools' Children Related to the Selected First Aid. Am J Nurs Res. 2018;6(4):158-63.

[16] Saqer, Ahmad Osama DOM. Knowledge and attitude towards first aid: A cross-sectional study in the United Arab Emirates. J Anesth Clin Res. 2019;09(10):1-7.

[17] Başer M, Çoban S, Taşci S, Sungur G, Bayat M. Evaluating First-aid Knowledge and Attitudes of a Sample of Turkish Primary School Teachers. Vol. 33, Journal of Emergency Nursing. 2007. p. 428-32.

[18] Adib-Hajbaghery M, Kamrava Z. Iranian teachers' knowledge about first aid in the school environment. Chinese J Traumatol English Ed [Internet]. 2019;22(4):240-5.
Available from: https://doi.org/ 10.1016/ j.cjtee.2019.02.003

[19] Mpombo DAK, Mwanakasale V. Assessment of knowledge, attitude and practice of first aid amongst minibus drivers, conductors and road traffic police officers in Ndola, Zambia. Asian Pacific J Heal Sci. 2017;4(3):121-8.

[20] Vishma B K SMSM. Perception and Practices Regarding First-Aid among Nursing Students in. Int J Heal Sci Res. 2014;4(12):84-8.

[21] Joseph N, Narayanan T, Bin Zakaria S, Nair AV, Belayutham L, Subramanian AM, et al. Awareness, attitudes and practices of first aid among school teachers in Mangalore, South India. J Prim Health Care. 2015;7(4):274-81.

[22] Sonavane R, Kasthuri A, Kiran D. Knowledge and assessed practice regarding first aid among mothers of under 15 years children - A community based study in a rural area of south India. Int J Community Med Public Heal. 2016;(October 2014):603-6.

[23] Ray AS. Snake Bite its First Aid \& Anti Snake Venom ( ASV ): Details Guidelines. PharmaTutor. 2014;2(10):85-8.

Citation: Dr. Shivabasayya and Dr. Gulappa Devagappanavar, "Assessing the Impact of Short Training on First-Aid among Government Employees and Community People in the Rural Parts of Karnataka", International Journal of Research Studies in Medical and Health Sciences. 2020; 5(9): 22-28.

Copyright: ( 2020 Dr. Shivabasayya and Dr. Gulappa Devagappanavar, This is an open-access article distributed under the terms of the Creative Commons Attribution License, which permits unrestricted use, distribution, and reproduction in any medium, provided the original author and source are credited. 